\title{
Must We Protect Foreign Investors?
}

\begin{abstract}
Investment protection clauses, and the investor-state dispute settlement (ISDS) mechanisms they enable, have become a common feature of international agreements on trade and investment. Intended to promote foreign investment, these protections may also discourage governments from regulating in the public interest. This raises challenging normative questions about the rights of investors and distributive justice. In this paper, I argue that a global investment regime that disadvantages developing countries and socially disadvantaged groups is prima facie unfair. This conclusion must be defended against the claim that investors have certain independent moral rights to have their property protected, regardless of the distributive consequences. Granting the premise that such investor rights exist, I argue that these cannot plausibly ground a general rule against public interest regulation that undermines the value of property. I conclude that even if foreign investors have rights that must be safeguarded, the current investment regime must be reformed.
\end{abstract}

Running title: Must We Protect Foreign Investors?

Keywords: foreign investment, investor-state arbitration, distributive justice, property rights

\section{Introduction}

Transnational corporations and other private actors exert increasing influence over the formulation of policies that were once the sole province of sovereign states. Nowhere is this clearer than in the investor-state dispute settlement (ISDS) mechanisms that have become part and parcel of many international treaties on trade and investment. Through these mechanisms, foreign investors are given a private adjudicatory channel 
to challenge regulations that they perceive to breach treaty obligations, paradigmatically through a violation of their property rights. A potential conflict between the public interest and the rights of investors is thrown into sharp relief.

Consider the following cases. In 2007, a group of European investors launched a dispute against South Africa, which, as part of a positive discrimination law intended to mitigate the economic legacy of Apartheid, required mining companies to transfer part of their profits to black investors. The dispute was dropped a few years later after the claimants were given mining licenses with substantially lower levels of divestment. In 2009, the Swedish energy company Vattenfall demanded over $€ 1$ billion in compensation from Germany for imposing environmental restrictions on the construction of a proposed coal-fired power plant near Hamburg. The case was settled after the German government agreed to soften the restrictions. In 2010, tobacco multinational Philipp Morris brought Uruguay before an arbitration tribunal for passing laws requiring large graphic health warnings on cigarette packs, as well as other public health measures. The country spent $\$ 27$ million in its defence-more than the compensation demanded by Philip Morris — and though the tribunal ruled in favour of Uruguay and ordered a partial compensation of its legal costs, many observers fear that the mere risk of litigation may exert a 'chilling effect' on other countries entertaining similar policies.

The investment protections that provide the basis for these lawsuits raise challenging normative questions. One of these questions concerns their distributive effect. For some, international investment agreements are a step towards a more integrated and efficient world economy. By incentivising foreign investment, the claim goes, investment protections are bound to benefit everyone, including capital-importing developing countries. For others, however, they are a way for transnational corporations to increase their profit margins by unravelling environmental, public health and labour standards that tend to benefit the worst off. What constitutes a fair distribution of the benefits and burdens of foreign investment?

There is also a second question. According to an influential view, investment protections are not simply tools to increase efficiency in global markets for capital, but protections of the moral rights of investors. The investment protections in the North American Free Trade Agreement (NAFTA), for example, mirror the language in the Universal Declaration of Human Rights, and it is increasingly common for arbitrators 
to look to international human rights law to interpret substantive and procedural standards in the treatment of foreign investors (Isiksel 2016, p. 311; Kube and Petersmann 2016). If investors have certain moral rights that investment agreements are meant to safeguard - in particular rights to property — then the fact that these agreements have unwelcome distributive repercussions may not be a decisive reason to reject them. Hence we must also ask about the content of the alleged moral rights of investors.

Although normative political theorists have in recent years begun to examine the global economy from many different angles, little attention has been paid to these questions. ${ }^{1} \mathrm{My}$ intention is to help fill this gap. After providing a brief overview of the features of the modern global investment 'regime' (section 2), I examine it from the point of view of distributive justice (section 3). Drawing loosely on Aaron James' work, I employ a constructivist methodology to weigh the benefits of investor protection clauses against their risks and harms. I suggest that developing countries are not likely to be major beneficiaries of these clauses, and the same is true in particular of the disadvantaged groups within these countries. This is a pro tanto reason to reject investment protection clauses from the point of view of justice. However, to draw this conclusion we must address the claim that these clauses protect natural moral rights to property (section 4). Drawing an analogy with the human right to migrate, I show that even if such rights exist, they cannot plausibly be thought to undermine the right of states to regulate in the public interest, as long as these regulations conform to the rule of law. The final section summarises.

\section{The Global Investment Regime}

Foreign investment law is one of the fastest growing and most dynamic areas of international law. There are now over 5,000 international investment agreements, including approximately 3,000 bilateral treaties, or BITs (Subedi 2016, p. 1). The first wave of these treaties dates back to the post-war period. In a climate in which newly independent developing countries sought to exercise sovereignty over economic matters, Western investors increasingly came to see existing protections against expropriations in

\footnotetext{
${ }^{1}$ There are a handful of recent exceptions, including (James2017); (Banai 2017) and (Dietsch 2017).
} 
international law as insufficient. Starting with a BIT between West Germany and Pakistan in 1959, thousands of investment treaties were signed by states around the world. Over time, investment protection provisions were also included in broader international economic agreements such as the North American Free Trade Agreement (NAFTA), the Energy Charter Treaty, or the proposed Trans-Pacific Partnership (TPP). Even as the outright expropriation of assets became rare, the number of investment protection clauses soared, for they were now seen to protect foreign investors from indirect risks associated with changes to the regulatory environment in host countries. $^{2}$

One of the most remarkable developments within the proliferation of international investment agreements is a transformation in the mode of business dispute resolutions. In early BITs, disputes about the treatment of foreign investors were either submitted to the International Court of Justice, or solved between the governments of the host country and the investor's country. Gradually, however, more investment agreements began to include mechanisms of dispute settlement by arbitration between host countries and foreign investors. What was once an international affair became truly transnational: private actors were given the right to take countries to court directly if treaty obligations were (thought to be) violated. This is a right investors have been increasingly keen to exercise. Only 43 investor-state arbitrations had been initiated up until the late 1990s, but there have been over 800 since the year 2000. ${ }^{3}$ While this may still be a modest number - at least in relation to the overall volume of investment flowsthe trend clearly points upwards.

The respondents in these cases are usually developing countries; the claimants typically transnational corporations. Significant sums of money are often at stake: in one of the largest and most publicised cases, for instance, Ecuador was asked to pay $\$ 2.3$ billion in damages to a US oil company. ${ }^{4}$ This sum has since been renegotiated to $\$ 1$ billion, but this still represents around a quarter of the Ecuadorian government's total

\footnotetext{
${ }^{2}$ For a brief historical account of the development of international investment law, see (Dolzer and Scheuer 2012, Ch. 1).

${ }^{3}$ See the United Nation Conference on Trade and Development's (UNCTAD) Investment Policy Hub, available at: http://investmentpolicyhub.unctad.org/ISDS (accessed May 15, 2018).

${ }_{4}^{4}$ The company, Occidental Petroleum, had breached Ecuadorian law by selling off drilling rights without the government's permission, prompting the latter to seize their oil fields. Although the arbitrators agreed that the government had acted lawfully, they nevertheless found that it had violated an Ecuador-USA BIT. Occidental v. Ecuador, ICSID Case No. ARB/06/11, available at: https://www.italaw.com/cases/767 (accessed May 15, 2018).
} 
yearly health expenditure. ${ }^{5}$ Because arbitration awards can be so consequential, the mechanisms of investment arbitration have come under scrutiny. Most disputes are settled under the rules of the Convention on Settlement of International Investment Disputes (ICSID Convention) or those of the United Nations Commission on International Trade Law (UNCITRAL). The decisions are taken by a panel of three arbitrators, sometimes in secret, and generally with little public scrutiny or accountability. Decisions are final and there is no right of appeal. The identity of arbitrators is a particularly controversial point: hired on a case-by-case basis, some arbitrators work as corporate lawyers for the same kinds of companies whose cases they hear, giving rise to worries of a 'revolving door' (Langford, Behn and Lie 2017). Of those arbitration decisions that have been publicised, about $37 \%$ have been decided in favour of the state and $28 \%$ in favour of the investor. In $23 \%$ of the cases, states have decided to settle. $^{6}$

Unlike in the case of global trade, there is no multinational organisation that governs global investment, and the thousands of international investment agreements in existence are legally separate documents. Nevertheless, most observers speak of an emerging 'regime' in global investment, that is, a 'set principles, norms, rules, and decision making procedures around which actor expectations converge. ${ }^{77}$ For one thing, investment protection provisions in different agreements are remarkably similar in language and content, often down to the very same formulations. They typically include reference to a standard of 'fair and equitable treatment' of investors, for example, although this standard is seldom further defined. Indeed, as one observer puts it, investment protection clauses are breathtaking in their generality, vagueness and lack of specificity' (Salacuse 2010, p. 453). This, in turn, leaves plenty of interpretive room for arbitrators, who effectively not only settle disputes, but further elaborate and thereby shape the very meaning of the treaties. It has also become common for arbitrators to

\footnotetext{
${ }_{5}^{5}$ World Bank Open Data 2018. Available at: https://data.worldbank.org/country/ecuador (accessed May 15, 2018). ${ }^{6}$ UNCTAD Investment Policy Hub, available at http://investmentpolicyhub.unctad.org/ISDS (accessed May 15, 2018).

${ }^{7}$ This is Stephen Krasner's (1982, p. 185) classic general definition of a regime. For an application of regime theory to global investment, see in particular (Salacuse 2010). While it is sometimes said that the regime is not truly global due to a relative lack of BITs between capital-exporting countries, this seems to be changing as the latter are increasingly also becoming respondents of investor-state disputes. Hence investment law is 'developing toward an increasingly universal regime that can come into play independently of the sources and targets of foreign investment flows.' (Schill 2009, p. 371).
} 
reference arbitral decisions pertaining to different treaties. This progressive growth of investment case law 'creates more opportunities for private actors to bring claims against sovereign states, gradually establishing a feedback loop that promotes further development of the regime, often in directions not envisaged by the signatories' (Isiksel 2016, p. 307).

Given this unpredictability, one may wonder why states are willing to sign up to the global investment regime. The most popular explanation, in particular with view to investment treaties between rich and poor countries, is that the regime is founded on a 'grand bargain:' 'a promise of protection of capital in return for the prospect of more capital in the future' (Salacuse and Sullivan 2005, p. 77). To put the same point somewhat differently, countries choose to increase their credibility in the eyes of investors by ceding part of their sovereignty. In doing so they also improve political relations between countries: BITs may be seen as a sign of good will, and they externalise diplomatic tensions by allowing investors to settle disputes directly with host states. Other interpretations are less benign. Views associated with the realist school in International Relations, for example, see regimes as means for hegemonic powers to impose their strategic interests (e.g. Crawford, 1996). Yet another possibility is that the investment regime is neither the product of rational bargaining nor coercion, but rather a result of 'bounded rationality:' when they signed investment treaties, many countries may have overestimated their benefits while underestimating (or entirely ignoring) the possible costs of ISDS (Poulsen 2015).

Regardless of why states sign investment agreements, there is an emerging global regime with significant legal, political and socio-economic repercussions. Alternative ways of structuring the regime have different distributive outcomes. Like with all socially alterable arrangements that shape our lives, this raises the question of justice, to which I turn now.

\section{Distributive Justice}

Not too long ago, the literature on global justice seemed to offer a stark choice. Globalists maintained that certain distributive principles applied to the global institutional order as a whole. The justice of particular social arrangements, such as those governing global investment, would then have to be judged by whether they promoted those 
principles (for example, a Rawlsian difference principle applied to all people in the world). Statists, in contrast, were defined by their scepticism about the applicability of the concept of distributive justice beyond the state. Although the distributive impacts of international arrangements could still be seen as a matter of domestic or social justice, norms specific to the global realm were limited to human rights, and minimal procedural standards in the interaction between sovereign states.

This, of course, is a rather crude picture of the global justice debate. The reader will no doubt suspect my intentions, namely to show a third way beyond the dichotomy I have just set up. In broad brushstrokes: instead of thinking of the global realm as a single entity to which considerations of distributive justice either apply or don't apply, we can look at individual global practices, institutions or regimes as separate sites of justice (see e.g. De Bres 2012). Some principles of justice will then apply to the rules that govern international migration, for example, other principles will apply to questions of global environmental justice, and yet others to the global intellectual property rights regime. We need not deny that there are linkages between these separate subjects of global justice, and that these will influence the content of their demands. But neither should this stop us from focusing on specific aspects of the global order in this pluralistic fashion.

An influential example of how this approach might look is Aaron James's book Fairness in Practice: A Social Contract for The Global Economy (2012). James proposes to understand the global economy as an independent social practice, one in which countries mutually rely on common markets for the purpose of increasing their national incomes. By integrating their economies, countries enjoy a claim to a fair share of the overall gains that the practice gives rise to. What fairness demands, in James's account, is established through a constructivist moral methodology in the style of Scanlon (1998) and Rawls (1971). We consider all relevant interests at stake by imagining what principles for the global economy would be chosen behind some suitably designed veil of ignorance. James claims that the resulting principles would be substantially egalitarian: not only should the gains from international cooperation be distributed equally among countries, citizens within each country ought to receive an equal share of their country's share.

We need not agree with all aspects of James's account to appreciate the usefulness of the general approach. First we identify and interpret the social meaning of a given 
practice: the global economy, or more specifically, the global investment regime. ${ }^{8}$ Then we put ourselves in everyone else's shoes, as it were, to see how the practice might be structured fairly in light of its meaning. Again, I do not necessarily think that we must accept James's strongly egalitarian principles. But through the exercise of identifying the morally relevant interests at stake, and imagining what terms would be acceptable to each party involved, we get a good idea of what would certainly not count as a fair global investment regime. In other words: we need not find principles for an ideally just regime but may instead merely highlight arrangements that participants in the practice could reasonably reject as unjust. That is the approach I want to pursue here.

Let me begin with the rather banal observation that the practice of foreign investment is meant to be beneficial to all parties involved. Investors stand to make a profit by bringing their capital to countries with favourable conditions for a high rate of return; host countries can hope for skill and technology transfers, economic growth, and more jobs. That, in essence, is the basis of the bargain. Now, without any kind of assurance towards investors, host countries would hold the upper hand: once the investment had sunk in, they could expropriate assets, increase tax rates, revoke licenses, and so on. Investment protections are therefore designed to level the balance of power. And to that end, host countries must give up something: they must make assurances to investors that limit their own freedom of action.

A first thing to note is that, for the bargain to be fair, the costs of incentivising foreign investment must arguably stand in relation to the benefits. It is an empirical question just how much investment treaties really attract investment. Perhaps surprisingly, the evidence shows a rather mixed picture. While some studies predict that countries can double their share of foreign investment by signing many BITs (Neumayer and Spess 2005), others are more sceptical. Countries with weak domestic institutions have not received significant additional foreign investment, for example, and in those with strong institutions, the causal effect of investment treaties is unclear (HallwardDriemeier 2003; Yackee 2008). The promise of ISDS is certainly not always decisive. In the opinion of a former acting US Trade Representative, for example, investors

\footnotetext{
8 James (2017, p. 207) understands the global investment regime, together with the global trade regime built around the World Trade Organization (WTO), as 'expressions of a common underlying economic practice.' But even if we want to analyze the investment regime separately, our conclusions are not likely to differ much: Investment, like trade, is a practice designed to augment national incomes, and the relevant actors and interest at stake are largely similar.
} 
rarely, if ever, enter a foreign market because of ISDS protections' (Sapiro 2015, p. 20).

Regardless of whether any individual country can benefit from signing investment treaties, however, for the practice as a whole, at least some of the benefits will take the form of a zero-sum game. To be sure, the liberalisation of capital flows is likely to lead to some absolute economic gains. Under an efficient investment regime, where capital can seek out the highest rate of return, more investments will be made than under an inefficient alternative. In this sense, the total volume of investments is endogenous to the investment regime in place. But there are limits to this argument. For one thing, some investments are site-specific — think of natural resource extraction-and in these cases the mobility of capital is limited. Furthermore, capital is scarce, and countries compete for foreign investment. A credible assurance of investment protection may be a competitive advantage for any single country, but once all countries make similar assurances, the collective effect is a bidding contest that drives up concessions towards investors.

As Andrew Guzman has argued, international investment agreements take the form of a prisoner's dilemma for developing countries. While it may be preferable to sign a BIT with a capital-exporting country rather than to miss out on possible investments, a worldwide network of investment agreements is a worse outcome than a world in which no investment agreements existed. Even if an efficient global investment regime brought a total increase in welfare, it is likely that 'this gain will be outweighed by the loss those countries will suffer as they bid against one another to attract investment' (Guzman 1998, p. 688). In a competitive market for capital, most of the benefits of investment will go to the investor, and not to the host states - in particular not to those who depend heavily on foreign capital, namely developing countries. ${ }^{9}$ It is these countries that have strong reasons to reject a global investment regime that is heavily skewed in favour of the investor.

The claim here is not that investors and host countries must profit equally in order for the global investment regime to be fair, let alone that developing countries must be offered the best possible terms. Rather, the point is that the current regime must at least produce a net benefit for its least advantaged participants. Developing countries

\footnotetext{
9 As Beth Simmons (2014) has shown, the weaker a developing country's own economic prospects, the stronger the constraints on its freedom of action it is willing to accept.
} 
can reasonably reject any arrangement that renders them worse off in relation to this minimal baseline. This would be the case if the benefits of investment treaties were negligible, as some of the literature suggests, or if modest benefits were outweighed by the costs of concessions towards investors. If either of these empirical claims is true, the current investment regime could not be justified to some of its participants. Note that this is a modest claim. With regard to the global trade regime, for instance, it is often argued that people in developing countries benefit from liberalisation even if they suffer exploitation or other disadvantages (e.g. Van der Vossen and Brennan, forthcoming). Because of the undeniable welfare gains that free trade produces, people are better off than they would have been without the global trade regime. Whatever one makes of this argument (and one might well think that it sets too low a baseline), it is doubtful whether it can be applied to the global investment regime.

A further concern arises when we look not only at the distribution of costs and benefits between investors and host countries, but also at the distributive effects within the latter. So far I have been writing about the costs to host countries in a rather abstract way. There are, of course, the concrete costs of compensating investors when arbitration tribunals find fault with certain policies - costs, as we have seen, that may sometimes amount to billions of dollars. But perhaps more importantly, host countries also make concessions to investors by restricting their own policy space and ceding part of their sovereignty through ISDS. Policy space and sovereignty may or may not be intrinsically valuable, but they certainly have an instrumental value: freedom is always freedom to do (or not to do) something. And the options that are foreclosed or made more costly by investment protection clauses may benefit or disadvantage people within a given host country to different degrees. In other words, the design of the global investment regime has distributive implications within host countries as much as across them.

Recall that investment protection clauses are meant to protect not only against the direct expropriation of assets, but also what is known as 'indirect expropriation,' that is, measures and policies that have the effect of undermining the value of the investment. Typical examples are environmental and labour laws. In developing countries, lower standards in these areas often constitute part of the economic potential that the host country offers. That in itself may be good. But it becomes problematic when investment treaties have the effect of locking countries into these lower standards, 
since the protection of investors' 'legitimate expectations' can be interpreted as part of a 'fair and equitable treatment.' Take for instance the case of Tecmed, a Spanish company that had purchased a landfill facility near Hermosillo, Mexico in 1996. At the time of the purchase, there were national environmental regulations in place that required landfills to be located at a minimum distance to major settlements. Though the landfill facility in question violated them, these regulations were never enforced. However, after the purchase by Tecmed, a newly elected local government, responding to sustained protests from local residents, decided to revoke the company's license. Tecmed filed a claim under a Spain-Mexico BIT, and the tribunal confirmed that the claimant could have legitimately expected the regulation not to be enforced. ${ }^{10}$

Granted, investment treaties also typically contain public interest provisions, exempting host countries from paying compensation for passing reasonable and necessary legislation affecting public safety, health, or morals. Yet like the 'fair and equitable treatment' standard, the vagueness of these provisions leaves much room for interpretation to the arbitration tribunals. Even when arbitrators uphold the state's right to legitimate regulation, the uncertainty of their decision-making may already be a risk and a deterrent to any government entertaining the policies in question (see e.g. De Ville and Siles- Brügge 2016).

What makes this problematic from the point of view of distributive justice, of course, is that the largest potential beneficiaries of public interest regulations are the socially disadvantaged groups within the host countries. Labour legislation, such as minimum wage laws, often benefit the poor. Environmental legislation, such as restrictions on mining, often benefit rural populations. The investment regime may thus have the effect of improving profit margins for foreign investors at the cost of these groups. Furthermore, while investment protection clauses allow investors to pursue their interests through the ISDS system, no similar privilege is afforded to host countries, nor affected groups within host countries. Since investors are not signatories to international investment agreements-only states are-they cannot be taken to court for, say, breaching environmental standards or failing to pay taxes. As some observers have put it, the domestic equivalent of the global investment regime would be the

${ }^{10}$ Tecmed S.A. v. The United Mexican States, ICSID Case No. ARB (AF)/00/2. Available at: https://www.italaw.com/cases/1087 (accessed May 16, 2018). See also (Isiksel 2016, pp. $336 f f$ ). 
reinstatement of property requirements as a condition of voting rights: 'only those with capital [...] have a voice' (Garcia et al. 2015, p. 875).

In sum, the distribution of benefits and burdens in the global investment regime stands in need of justification. It seems clear that foreign investors are the major beneficiaries of the current arrangements. That in itself may not necessarily be unfair, as long as the economic pie as a whole is growing (see also Dietsch 2017). But when the effects of investment treaties on employment and growth are uncertain or marginal, or when the benefits to developing countries are outweighed by costs that are primarily borne by the worst-off, the latter can reasonably reject the terms of the regime. It is worth noting again that while this conclusion depends on empirical claims about the effects of investment agreements—about which the jury is still out-it does not depend on adopting strongly egalitarian distributive principles along the lines of James's theory.

\section{Investor Rights}

It might be objected that our discussion thus far has failed to address what is perhaps the central concern behind investment protection clauses. Rather than being simply instruments to incentivise foreign investment, the objection goes, these protections are meant to safeguard the moral rights of investors. If investors have independent rights not to be treated in certain ways, then it matters little whether or not others are likely to benefit from the recognition of these rights. We cannot allow foreign investors to be arbitrarily deprived of their property in the name of distributive justice, much like we cannot forcibly redistribute kidneys to those in need. In our pursuit of fair distributive outcomes, these rights act as 'side-constraints,' to use Robert Nozick's wellknown expression.

What kinds of rights do investors have? Investment agreements typically include, among other things, protections against discrimination and rights to a 'fair and equitable' treatment. However, the core of the claim about investors' rights is arguably the right to property. Since the concept of expropriation is commonly interpreted in such 
a broad way as to include any unjustified threat to the commercial interests of investors, all these other rights can be thought to derive from the right not to have one's property arbitrarily deprived.

This then immediately gives rise to a question about the nature of property rights. According to one view-long associated with John Locke-people have natural rights to their property, and these rights are conceptually prior to any legal or political arrangement that recognises them. In a world in which there were no investment protection provisions, they would need to be invented. Call this the natural rights view. A second view, in contrast, holds that property rights only exist through the arrangements that recognise them. As David Hume put it:

Our property is nothing but those goods, whose constant possession is establish'd by the laws of society; that is, by the laws of justice. [...] Tis very preposterous, therefore, to imagine, that we can have any idea of property, without fully comprehending the nature of justice (1978/1739, p. 491).

From this point of view, we would need to know what a just global investment regime looks like in order to specify the content of investor rights. Call this the institutional view.

This latter view has recently been defended by Aaron James, for whom natural investor rights amount to what Jeremy Bentham would have called 'nonsense upon stilts.' Because investing in a foreign country is a kind of gamble, James argues, giving investors special protections is akin to allowing unlucky players to sue the casino for damages. No fair institutional arrangement would allow this. All that foreign investors can reasonably expect under a fair investment regime is not to be subjected to what he calls 'infidelity.' This includes being misled about the risks and prospects of doing business in a country, and not being given a 'fair warning' about changes in the regulatory environment. Claiming rights to anything beyond that is simply nonsense, unless they are based on contractual obligations. But such obligations-if they amount to more than a guarantee against infidelity—-would not be part of a just investment regime (James 2017).

As should be clear now, the conflict between distributive justice and the rights of investors all but disappears on the institutional view. This is so because the content 
and the contours of property rights would need to be established in light of the distributive implications that these purported rights would have. Even though I am in principle sympathetic to this way of thinking about property rights, however, it seems to me that James' argument takes the truth of the institutional view for granted. It leaves no room for the idea that there are certain universally valid standards that are not derived from an institutional framework that allocates rights and duties - an idea that seemingly underlies the widespread references to human rights in the discourse on foreign investment.

To illustrate what is at stake here, take the rather minimal rights against infidelity that James thinks would be accorded to investors in a fair investment regime. If these rights are all there is, investors can either accept the risks of moving their capital to a given country, or go elsewhere if they deem these risks too high. However, a proponent of the natural rights view would insist that investors enjoy certain rights wherever they go. A woman who accepts a job in a misogynistic society does not lose her human right to be treated in ways that reflect her equal moral status. A gay tourist travelling in a homophobic country does not thereby forfeit his human right to be free of discrimination on account of his sexual orientation. And foreign investors who invest in countries with shaky property rights records, so the argument goes, do not thereby give up any claims to compensation should they be wronged. Merely being warned about risks is not enough, for the risks themselves may constitute a violation of one's rights.

That is the view that I want to examine. Instead of attempting to show the superiority of the institutional view, I shall accept, for the purposes of the argument, that the natural rights view is correct. In trying to make sense of it, we can then explore what exactly the property rights of investors amount to, and how far they would take us in justifying the investment protection provisions discussed above. But in order to do so, we must first say a little bit more about the structure and justification of the right in question.

As is often pointed out, the right to property is not a single right but a bundle of rights (Honoré 1961). To own a sewing machine, for example, means to have a right to use it, to exclude others from its use, to keep the income it generates, to trade it for a piece of land, to give it away, and so forth. More importantly for our purposes, if investors have rights anything like the ones we are envisaging, the right to property would also include a right to move one's property across borders, and to enjoy the 
same bundle of rights there. Investor rights are rights to deploy one's property without geographical limitations. Why should we think that the right to property extends in this way, especially given that under international law, sovereign states have the right to impose the terms under which foreigners conduct business in their jurisdictions? (Cf. Wenar 2016, pp. 106f.). Well, again, we are here entertaining the idea of a natural moral right to invest, which may well be in conflict with the political and legal institutions that we take for granted today.

In order to have any moral right, I shall assume, it must be true that the right protects an interest that is weighty enough to place others under correlative duties (See Raz 1986). What interests are protected by the bundle of rights that we commonly associate with the right to property? One line of argument (associated, among others, with Hegel) emphasises the importance of private property for our ethical development as free persons. When we hold property rights over things, the argument goes, this secures 'a sphere of personal jurisdiction, the right to acquire and hold the props, as it where [sic], with which to order one's life' (Machan 2001). A second argumentative strand (associated primarily with Locke) emphasises people's interests in self-ownership and the way it is extended to resources by mixing one's labour with them. Having control over the things one has legitimately appropriated, on this view, is akin to having control over one's own self. ${ }^{11}$

I shall not attempt to develop a detailed positive account of either of these arguments in the context of global investment, nor to deal with the associated theoretical issues (among other things, the question whether corporate agents, such as transnational corporations, can be said to have an interest in their ethical development). As a friendly gesture towards the proponents of investor rights, I shall assume these issues can be dealt with appropriately, and that there is a general link between freedom and the right to property that is worth protecting. I am happy therefore to shift the burden of proof to those who object to the economic liberties associated with the right to property. However, I want to show that even if we are sympathetic to the idea of natural investor rights, there are limits to what follows from them. To illustrate this point, I want to compare the right to property of investors - in particular their right to

\footnotetext{
${ }^{11}$ For a thorough examination of these two kinds of arguments, see (Waldron 1990).
} 
move their property across international borders - with another right that shows considerable structural similarities, the alleged human right to migrate.

Some philosophers have argued in recent years that the freedom to move across borders is necessary to protect a fundamental interest in exercising a range of different life options. These options may relate, for example, to jobs, family and friends, or civic and political association with others. The fact that we need to move places in order to access these life options is commonly thought to justify domestic freedom of movement, but since many life options lie outside the borders of our home state, the same logic would lead us to accept a global right to migrate (Oberman 2016; Carens 2013). Now, of course, such a right is not widely recognised within political philosophy (let alone outside it). But comparing and contrasting it to the right to invest may nevertheless give us some insight as to the possible nature and limits of the latter.

Indeed, the argumentative structure of both purported rights is similar: they identify an important interest, show how it justifies a domestic right, and finally go on to 'globalise' it by parity of reasoning. Beyond the structure of the argument, the content of the protected interest is similarly general in its appeal to freedom or liberty. ${ }^{12}$ And it is explicitly not understood along sufficientarian lines: it is not enough to offer merely an 'adequate' range of life options within a geographically constrained area, according to the proponents of the human right to migrate. Only a global interpretation is thought to satisfy the interest at stake. Similarly, the logic of the right to private property does not imply any geographical limit as to where we may use it, transfer it, alienate it etc. This should not surprise us, of course, since we have defined these rights in a pre-institutional or pre-political way.

And yet, the fact that these rights are understood as pre-political cannot mean that their precise content or value is independent from politics. Consider, for example, how the human right to migrate must presuppose some account of the sorts of entitlements that immigrants are to enjoy in their countries of destination. Surely the right to migrate would be meaningless if states imposed no restrictions on entry, but then consigned all new arrivals to rat-infested dungeons (See Miller 2016). On the other hand, the proponents of the right do not claim that in order for it to be realised, all immigrants

\footnotetext{
${ }^{12} \mathrm{It}$ is interesting to note that freedom of movement and of capital are two of the four basic freedoms of the European Union. They are usually presented as inseparable, and the discourse of at least some politicians in Brussels suggests that this is not merely on economic, but also moral grounds.
} 
must immediately be given the full set of privileges that citizens enjoy. Between these two extremes, there is a number of plausible scenarios that are compatible with the purported human right to migrate. What precisely the terms of membership are will be decided by the receiving society through their own political means. And we can even go further: it is precisely the fact that different societies make different political choices that creates the diversity in 'life options' that the right to migrate is meant to secure access to.

I think that something similar can be said about investor rights. If there is a natural right to property, its value cannot be insulated from the political and legal environment in which property is held. To be sure, if an investor buys a piece of land in a foreign country only to have it expropriated without any explanation shortly thereafter, her rights have been violated. Or, like the immigrants in the rat-infested dungeons, she is holding a meaningless right. But imagine that the authorities in that foreign country decide, through democratic means, to restrict the use of land for hydraulic fracturing ('fracking') near residential areas. Let's also image that that was the primary intent of the investor. Has her right to property been violated? It would not be accurate to say that she no longer owns the land. Out of the bundle of rights that her property gives rise to, she still enjoys all but one (i.e. the right to use it specifically for fracking). Still, the question is whether this change in the regulatory environment is wrongful.

Consider now a different example. Imagine someone invests in real estate near a prison, anticipating profits from renting homes to correction officers. Somewhat later, the harsh and discriminatory drug laws that were in force at the time of the investment are repealed, resulting in fewer inmates and less demand for housing. ${ }^{13}$ Here too, the value of the investor's property decreases because of a change in the regulatory environment. But I think that in this case we are more confident in ruling out any violation of property rights. The example goes to show that virtually any change in the background rules that govern a society can affect the value of people's property (positively for some and negatively for others). To construe this as a violation of the right to private property is effectively to demand a form of legal and political stasis that is not only undesirable, but practically impossible. We may also add that, like in the case of the human right to immigrate, there is something self-defeating about such a demand.

\footnotetext{
${ }^{13}$ I borrow this example from Waldron (2012, p. 71).
} 
From the point of view of investors, it is precisely the diversity and the changing character of regulatory environments that create business opportunities.

What natural property rights do seem to entail, however, is that changes are brought about in ways that are not arbitrary or discriminatory. If the law banning fracking were tailored specifically to disadvantage foreign investors, it would be easy to see therein a wrongful attack on the kind of investor rights we are considering. But if the changes are brought about by procedures that are clear and transparent, laws that are formulated in general terms by legitimate law-making bodies, and interpreted and applied by independent judiciaries - in short, when these changes conform with the rule of law-it is hard to see an inherent conflict between regulation and property. Such a system, furthermore, is also able to determine fair compensation when appropriate. Indeed, it is along these lines that the right to property in the Universal Declaration of Human Rights is commonly interpreted: not as an imperative to homogenise the background constraints that regulate the possession and transmission of property in different legal systems, but rather as a general protection from legal arbitrariness (Cheneval 2006, p. 15). ${ }^{14}$

The rule of law is a more demanding standard than the one proposed by James. By ruling out only cases of infidelity, his account denies that investors are owed anything beyond a fair warning about the risks of moving their capital to a given country. The point of view of natural property rights, in contrast, demands a certain standard of legality even if the country in question is well known for failing to live up to it. It is true that investment is always a gamble. But the only risks that investors must accept on the view that we have sketched are those that do not arise from violations of their rights. All this notwithstanding, the point I have been making is that if we accept that there are natural investor rights (which James denies), it does not follow that changes to the regulatory environment will always violate those rights.

Let me now try to move back from this rather abstract discussion to the more applied question of investment protections and ISDS. I have suggested that the idea of natural investor rights does not rule out regulatory changes that undermine the value

\footnotetext{
${ }^{14}$ See also the $5^{\text {th }}$ Amendment of the US Constitution: 'no person [...] shall be deprived of life, liberty, or property, without due process of law; nor shall private property be taken for public use without just compensation.'
} 
of the investment, as long as these changes meet certain standards commonly associated with the rule of law. Of course, it would take more space than I have here to specify just what kind of standards these are. But let us suppose that at least some countries meet these standards, providing investors with a non-arbitrary and non-discriminatory business environment (including, for example, the possibility to appeal to independent courts against any perceived infringement of their property rights.) When countries that meet these standards sign investment agreements, it is not clear why respecting investor rights would require any further assurances. To take a recent example, many observers have doubted whether the Comprehensive Economic and Trade Agreement between the European Union and Canada (CETA) needs to include the ISDS mechanism, given the relatively high rule of law standards of all countries involved.

There are, of course, also harder cases. When countries cannot guarantee nonarbitrary and non-discriminatory business environments, the idea of natural investor rights does seem to suggest that a just global investment regime ought to include mechanisms that compensate for this shortfall. It does not follow, however, that ISDS in its current form is fit for this purpose. For if one of the rationales for protecting investments is the unpredictability of some governments, the same problem arises with arbitration tribunals. Consider, for instance, the two ISDS claims that were launched against the Czech Republic under a Czech-Dutch BIT in 2003. The first was brought by the owner of large media company; the second by the company itself. Although the circumstances of both claims were identical, the arbitration tribunal in the first case dismissed the claim out of hand, whereas the other arbitration tribunal found that the Czech Republic had grossly violated treaty obligations and was thus to pay $\$ 353$ million in damages (See Sweetland Edwards 2016, pp. 70ff.). There is nothing approximating a consistent and coherent jurisprudence in arbitration case law.

Similar assessments can be made with regard to other features that we associate with the rule of law: transparency, openness, independence, accountability, appellate review, and so on. ${ }^{15}$ If there are natural investor rights, securing them in countries with weak institutions would require the creation of global mechanisms that could live up to these standards. ISDS in its current form does not seem to be answer. Now, one

\footnotetext{
${ }^{15}$ For a comprehensive critique of ISDS on these grounds, see (Van Harten 2007, Ch. 7).
} 
might argue that if investor-state arbitration has a business-friendly bias, it may at least compensate for the insufficient protection of property rights in host countries, even if it does not itself advance the rule of law. But to the extent that it overcompensates, it could not be justified on the basis of natural property rights. At the same time, as we saw before, it could be rejected by other parties on the ground of distributive fairness.

\section{Conclusion}

The emerging norms and rules that govern foreign investment raise important worries that merit our attention. One of these is the way investment protection clauses, and the ISDS mechanisms they contain, impact host countries and their citizens. Though, compared to other areas of global justice, investment protections may still seem a rather marginal concern, they are indicative of a broader shift towards corporate interests in global and domestic politics. And this shift may involve distributive implications that stand in need of justification.

Following a broadly constructivist understanding of justice, I examined how investment protection clauses affect the relevant interests at stake. While some assurance towards investors is likely to lead to efficiency gains that benefit all, current ISDS practices seem to benefit investors above all. Developing countries that rely heavily on foreign capital are left with little choice but to grant maximal concessions to investors. And the costs of these concessions are primarily borne by the least advantaged social groups, who are typically beneficiaries of the public interest regulations that investors are wont to challenge. Even if we do not accept egalitarian principles in the distribution of gains and losses from global economic cooperation, the 'grand bargain' between investors and host countries seems worryingly one-sided.

A central objection to this line of argument is that investors enjoy certain prepolitical moral rights to have their property protected. From this vantage point, investment protection clauses are not something to be calibrated in light of their distributive effects, but rather an absolute requirement of a fair investment regime. But even if we accept that such rights exist, I argued, they cannot plausibly be understood to rule out policies and regulations in the public interest. The value of property rights is always linked to the background rules that govern a society, and it is both undesirable and impossible to expect those rules never to change. What can be expected, however, is 
that regulatory changes conform to the standards we commonly associate with the rule of law. To the extent that ISDS falls short of these standards, it cannot be justified by appeal to the moral rights of investors. Yet it may be reasonably rejected by those who incur its costs.

\section{Acknowledgments:}

I owe thanks to Chuck Beitz, Shuk Ying Chan and Harrison P. Frye for commenting on earlier drafts of this paper. I am also indebted to two anonymous reviewers and the editors of Moral Philosophy and Politics for their helpful suggestions.

\section{References}

Banai, A. (2017). 'Is Investor-State Arbitration Unfair? A Freedom-Based Perspective,' Global Justice: Theory Practice Rhetoric 10(1): 57-78.

Carens, J. (2013). The Ethics of Immigration (New York: Oxford University Press).

Cheneval, F. (2006) 'Property Rights as Human Rights,' in H. de Soto and F. Cheneval (eds.) Realizing Property Rights (Zurich: Ruffer and Rub), pp. 11-17.

Crawford, R. (1996). Regime Theory in the Post-Cold War World: Rethinking Neoliberal Approaches to International Relations (Brookfield: Dartmouth).

De Ville, F. and Siles-Brügge, G. (2016). TTIP: The Truth about the Transatlantic Trade and Investment Partnership (Cambridge and Malden, MA: Polity).

Dietsch, P. (2017). 'Growing the Pie or Slicing it Differently. On the Need to Disentangle Two Aspects of Trade Agreements,' Global Justice: Theory Practice Rhetoric 10(1): 43-56.

Dolzer, R. and Scheuer, C. (2012). Principles of International Investment Law. $2^{\text {nd }}$ ed. (Oxford, Oxford University Press).

Garcia, F. et al. (2015). 'Reforming the International Investment Regime: Lessons from International Trade Law,' Journal of International Economic Law 18(1): 861-892.

Guzman, A. (1998). 'Why LDCs Sign Treaties that Hurt Them: Explaining the Popularity of Bilateral Investment Treaties,' Virginia Journal of International Law 38: 639-688. 
Hallward-Driemeier, M. (2003). 'Do Bilateral Investment Treaties Attract Foreign Direct Investment? Only a Bit... and They Could Bite,'World Bank Policy Research Working Paper 3121.

Honoré, A.M. (1961). 'Ownership,' in A.G. Guest (ed.) Oxford Essays in Jurisprudence (Oxford: Oxford University Press), pp. 112-128.

Hume, D. (1978/1739). A Treatise of Human Nature. Edited by L.A. Selby-Bigge and P. H. Nidditch (Oxford: Clarendon Press).

Isiksel, T. (2016). 'The Rights of Man and the Rights of the Man-made: Corporations and Human Rights,' Human Rights Quarterly 38(2): 294-349.

James, A. (2017). 'Investor Rights as Nonsense—on Stilts,' in L. Herzog (ed.) Just Financial Markets? Finance in a Just Society (Oxford: Oxford University Press), pp. 205230.

Krasner, S. (1982). 'Structural Causes and Regime Consequences: Regimes as Intervening Variables,' International Organization 36(2): 185-205.

Kube, V. and Petersmann, E. (2016). 'Human Rights Law in International Investment Arbitration." Asian Journal of WTO \& International Health Law \& Policy 11: 65114.

Langford, M., Behn, D. and Lie, R.H. (2017). 'The Revolving Door in International Investment Arbitration,' Journal of International Economic Law 20(2): 301-332.

Machan, T. (2001). 'The Right to Private Property,' in: Internet Encyclopedia of Philosophy. http://www.iep.utm.edu/property (accessed 23/1/2018).

Miller, D. (2016). 'Is There a Human Right to Immigrate?' in S. Fine and L. Ypi (eds.) Migration in Political Theory. The Ethics of Movement and Membership (Oxford and New York: Oxford University Press), pp. 11-31.

Neumayer, E. and Spess, L. (2005). 'Do Bilateral Investment Treaties Increase Foreign Direct Investment to Developing Countries?' World Development 33(10): 15671585.

Oberman, K. (2016). 'Immigration as a Human Right,' in S. Fine and L. Ypi (eds.) Migration in Political Theory. The Ethics of Movement and Membership (Oxford and New York: Oxford University Press), pp. 32-56.

Poulsen, L.S. (2015). Bounded Rationality and Economic Diplomacy (Cambridge: Cambridge University Press).

Rawls, J (1971). A Theory of Justice (Cambridge MA: Harvard). 
Raz, J. (1986). The Morality of Freedom (Oxford: Oxford University Press).

Salacuse, J. (2010). 'The Emerging Global Regime for Investment,' Harvard International Law Journal 51: 427-74.

Salacuse, J. and Sullivan, N. (2005). 'Do BITs Really Work: An Evaluation of Bilateral Investment Treaties and Their Grand Bargain,' Harvard International Law Journal 46: 67-130.

Sapiro, M. (2015). 'Transatlantic Trade and Investment Negotiations: Reaching a Consensus on Investor-State Dispute Settlement,' Global Views (Brookings Institution) 5: $1-27$.

Scanlon, T.M. (1998). What We Owe to Each Other (Cambridge MA: Belknap).

Schill, S. (2009). The Multilateralization of International Investment Law (Cambridge: Cambridge University Press).

Simmons, B. (2014). 'Bargaining over BITs, Arbitrating Awards: The Regime for Protection and Promotion of International Investment,' World Politics 66(1): 12-46.

Subedi, S. (2016). International Investment Law. Reconciling Policy and Principle (Oxford: Hart).

Sweetland Edwards, H. (2016). Shadow Courts: The Tribunals that Rule Global Trade (New York: Columbia Global Reports).

Van der Vossen, B. and Brennan, J. (forthcoming). In Defense of Openness (Oxford: Oxford University Press).

Van Harten, G. (2007). Investment Treaty Arbitration and Public Law (Oxford: Oxford University Press).

Waldron, J. (1990). The Right to Private Property (Oxford: Oxford University Press).

Waldron, J. (2012). The Rule of Law and the Measure of Property (Cambridge: Cambridge University Press).

Wenar, Leif (2016). Blood Oil. Tyrants, Violence and the Rules that Run the World (New York: Oxford University Press).

Yackee, J. (2008). 'Bilateral Investment Treaties, Credible Commitment, and the Rule of (International) Law: Do BITs Promote Foreign Direct Investment?’ Law \& Society Review 42(4): 805-832. 